See Article page 1.

\section{Commentary: It looks good, but will it last?}

\author{
Rachel Eikelboom, MD, and \\ Michael H. Yamashita, MDCM, MPH, FRCSC
}

There is a global need for a prosthetic valve that has the durability of a mechanical valve that minimizes the risks of redo valve replacement yet has low thrombogenicity to avoid the lifelong systemic anticoagulation that is associated with morbidity and mortality. Chen and colleagues ${ }^{1}$ present the first-in-human results of a new bioprosthetic valve designed to achieve greater durability and a larger effective orifice area (EOA) than existing bioprosthetic valves. ${ }^{2,3}$

The authors present a series of 197 patients who received 161 aortic and 49 mitral Cingular (Shanghai Cingular Biotech Corporation, Shanghai, China) valve replacements. ${ }^{4}$ Their primary outcome was a composite of thromboembolism, valve thrombosis, major bleeding, major paravalvular leak, and prosthetic valve endocarditis, in accordance with the objective performance criteria established by the Society of Thoracic Surgeons (STS) for introduction of new prosthetic valves into the market. ${ }^{5}$ Transthoracic echocardiography at 1 and 12 months assessed EOA and incidence of patient-prosthesis mismatch.

The authors should be complimented on the excellent 1 -year results of their new bioprosthetic valve. These results must be interpreted in context of the study's nonrandomized nature and small sample size. The inclusion of both aortic and mitral valve replacements makes interpretation of results less clear; a case series of isolated aortic valve

\footnotetext{
From the Department of Surgery, Max Rady College of Medicine, University of Manitoba, Winnipeg, Manitoba, Canada, and Cardiac Sciences Program, St Boniface Hospital, Winnipeg, Manitoba, Canada.

Disclosures: The authors reported no conflicts of interest.

The Journal policy requires editors and reviewers to disclose conflicts of interest and to decline handling or reviewing manuscripts for which they may have a conflict of interest. The editors and reviewers of this article have no conflicts of interest.

Received for publication April 15, 2020; revisions received April 15, 2020; accepted for publication April 16, 2020; available ahead of print June 3, 2020.

Address for reprints: Michael H. Yamashita, MDCM, MPH, FRCSC, Cardiac Sciences Program, St Boniface Hospital, Y3519-409 Tache Ave, Winnipeg, MB, Canada R2H 2A6 (E-mail: myamashita@sbgh.mb.ca).

JTCVS Open 2020;2:12-3

2666-2736

Copyright $(2020$ The Authors. Published by Elsevier Inc. on behalf of The American Association for Thoracic Surgery. This is an open access article under the CC BY-NCND license (http://creativecommons.org/licenses/by-nc-nd/4.0/).

https://doi.org/10.1016/j.xjon.2020.04.004
}

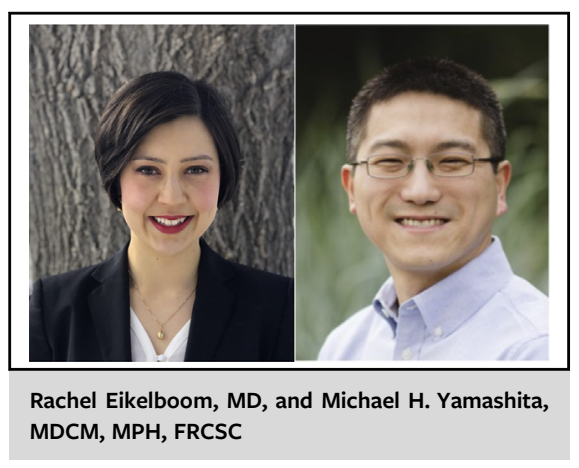

CENTRAL MESSAGE

Longer-term outcomes are

required to determine whether

the Cingular bovine pericardial

valve will maintain its excellent

1-year hemodynamics and prove

durable.

replacements would have been more straightforward. Furthermore, the study population had low surgical risk based on STS score and European System for Cardiac Operative Risk Evaluation II score; thus, selection bias may have an influence on these excellent results.

The authors report a low incidence of patient-prosthesis mismatch $(1.3 \%)$ and higher EOAs than seen in similarly sized bioprosthetic valves already on the market. It remains to be seen whether these results reflect the valve itself, or the population into which it was implanted. Chinese patients tend to have a lower average body surface area, and $40 \%$ received a 19- or 21-mm valve. The valve hemodynamics seen in this study may not be generalizable to all populations.

Two important questions remain regarding the Cingular valve. First, participants received warfarin with an international normalized ratio target of 2.5 for 3 to 6 months following valve replacement, which is supported by recent American Heart Association/American College of Cardiology guidelines. ${ }^{6}$ However, a recent STS survey revealed that most North American institutions treat patients with aspirin alone after bioprosthetic aortic valve replacement. ${ }^{7}$ It is not yet clear if the Cingular valve is sufficiently nonthrombogenic that once-daily aspirin would be safe in the first 3 months after implantation. Second, although the short-term results of the Cingular valve are encouraging, longer follow-up is required to determine durability. Other bioprosthetic valves also showed promising short-term 
results, but subsequent reports demonstrated these valves to be prone to early structural valve degeneration. ${ }^{8,9}$ We look forward to the 5-year and longer results of this study, which will help determine whether we are indeed 1 step closer to a durable prosthetic valve that does not require lifelong anticoagulation therapy.

\section{References}

1. Chen J, He C, Lv M, Guo Y, Tao L, Hong T, et al. One-year outcome with a bovine pericardial valve. J Thorac Cardiovasc Surg Open. 2020;2:1-11.

2. Chen J, Yang J, Zhang L, Ma W, Lu S, Wang C, et al. Optimizations of stent and tissue leaflets in a new surgical bovine pericardial valve. J Thorac Dis. 2019;11: 4855-8.

3. Chen JM, Ding Y, Lu SY, Pan S, Abudupataer M, Hong T, et al. Noninferiority of Shanghai Cingular Biotech's bovine pericardial valve preclinical study in juvenile ovine model. J Thorac Dis. 2016;8:1179-87.

4. Fox KAA, Eikelboom JW, Anand SS, Bhatt DL, Bosch J, Connolly SJ, et al. Anti-thrombotic options for secondary prevention in patients with chronic atherosclerotic vascular disease: what does COMPASS add? Eur Heart J. 2019; 40:1466-71.

5. Wu Y, Butchart EG, Borer JS, Yoganathan A, Grunkemeier GL. Clinical evaluation of new heart valve prostheses: update of objective performance criteria. Ann Thorac Surg. 2014;98:1865-74.

6. Nishimura RA, Otto CM, Bonow RO, Carabello BA, Erwin JP III, Fleisher LA, et al. 2017 AHA/ACC focused update of the 2014 AHA/ACC guideline for the management of patients with valvular heart disease: a report of the American College of Cardiology/American Heart Association task force on clinical practice guidelines. J Am Coll Cardiol. 2017;70:252-89.

7. Brennan JM, Edwards FH, Zhao Y, O'Brien S, Booth ME, Dokholyan RS, et al. Early anticoagulation of bioprosthetic aortic valves in older patients: results from the Society of Thoracic Surgeons adult cardiac Surgery national database. J Am Coll Cardiol. 2012;60:971-7.

8. Sénage T, Le Tourneau T, Foucher Y, Pattier S, Cueff C, Michel M, et al. Early structural valve deterioration of Mitroflow aortic bioprosthesis: mode, incidence, and impact on outcome in a large cohort of patients. Circulation. 2014;130: 2012-20.

9. Fukuhara S, Shiomi S, Yang B, Kim K, Bolling SF, Haft J, et al. Early structural valve degeneration of Trifecta bioprosthesis. Ann Thorac Surg. 2020;109 $720-7$. 